Article

\title{
Influence of Micron-Ti and Nano-Cu Additions on the Microstructure and Mechanical Properties of Pure Magnesium
}

\author{
Sankaranarayanan Seetharaman ${ }^{1, *}$, Jayalakshmi Subramanian ${ }^{1}$, Manoj Gupta ${ }^{1}$ and \\ Abdelmagid S. Hamouda ${ }^{2}$
}

1 Department of Mechanical Engineering, National University of Singapore (NUS), 9 Engineering Drive 1, Singapore 117576, Singapore; E-Mails: mpejs@nus.edu.sg (J.S.); mpegm@nus.edu.sg (M.G.)

2 Mechanical and Industrial Engineering Department, Qatar University, P.O. Box No. 2713, Doha, Qatar; E-Mail: hamouda@qu.edu.qa

* Author to whom correspondence should be addressed; E-Mail: seetharaman.s@nus.edu.sg; Tel.: + 65-93510324.

Received: 26 April 2012; in revised form: 6 August 2012 / Accepted: 10 August 2012 / Published: 17 August 2012

\begin{abstract}
In this study, metallic elements that have limited/negligible solubility in pure magnesium ( $\mathrm{Mg}$ ) were incorporated in $\mathrm{Mg}$ using the disintegrated melt deposition technique. The metallic elements added include: (i) micron sized titanium (Ti) particulates with negligible solubility; (ii) nano sized copper $(\mathrm{Cu})$ particulates with limited solubility; and (iii) the combination of micro-Ti and nano- $\mathrm{Cu}$. The combined metallic addition $(\mathrm{Ti}+\mathrm{Cu})$ was carried out with and without preprocessing by ball-milling. The microstructure and mechanical properties of the developed $\mathrm{Mg}$-materials were investigated. Microstructure observation revealed grain refinement due to the individual and combined presence of hard metallic particulates. The mechanical properties evaluation revealed a significant improvement in microhardness, tensile and compressive strengths. Individual additions of $\mathrm{Ti}$ and $\mathrm{Cu}$ resulted in $\mathrm{Mg}$ - $\mathrm{Ti}$ composite and $\mathrm{Mg}-\mathrm{Cu}$ alloy respectively, and their mechanical properties were influenced by the inherent properties of the particulates and the resulting second phases, if any. In the case of combined addition, the significant improvement in properties were observed in $\mathrm{Mg}-(\mathrm{Ti}+\mathrm{Cu})_{\mathrm{BM}}$ composite containing ball milled $(\mathrm{Ti}+\mathrm{Cu})$ particulates, when compared to direct addition of $\mathrm{Ti}$ and $\mathrm{Cu}$ particulates. The change in particle morphology, formation of $\mathrm{Ti}_{3} \mathrm{Cu}$ intermetallic and good interfacial bonding with the matrix achieved due to preprocessing, contributed to its superior strength
\end{abstract}


and ductility, in case of $\mathrm{Mg}-(\mathrm{Ti}+\mathrm{Cu})_{\mathrm{BM}}$ composite. The best combination of hardness, tensile and compressive behavior was exhibited by $\mathrm{Mg}-(\mathrm{Ti}+\mathrm{Cu})_{\mathrm{BM}}$ composite formulation.

Keywords: magnesium composites; metallic additions; mechanical alloying; microstructure; mechanical properties; Scanning Electron Microscopy (SEM)

\section{Introduction}

The growing demand for reduced fuel consumption and fuel energy savings in automobile and aerospace applications is constantly driving the materials community towards the development of new light-weight metallic materials [1,2]. Magnesium with density $\sim 1.74 \mathrm{~g} / \mathrm{cc}$, has the highest strength-to-weight $[\sigma / \rho]$ ratio among the available metals for structural applications. It is $\sim 35 \%$ lighter than aluminium $\left[\rho=2.7 \mathrm{~g} / \mathrm{cm}^{3}\right]$ and $\sim 65 \%$ lighter than titanium $\left[\rho=4.51 \mathrm{~g} / \mathrm{cm}^{3}\right][2-4]$. Hence, Mg-based materials are receiving increased attention for weight critical applications [4,5]. Further, the advantages of $\mathrm{Mg}$ materials include superior damping capacity, high specific stiffness, good dimensional stability, machinability and castability. Despite these advantages, the extended wide spectrum of applications of $\mathrm{Mg}$ materials is constrained by the low ductility and inferior fracture toughness, which is due to the hexagonal closed packed crystal structure of $\mathrm{Mg}$ [1-6]. Most of these limitations can be circumvented through the judicious addition of selective alloying elements such as $\mathrm{Al}, \mathrm{Zr}, \mathrm{Zn}$ and RE metals. Mg alloys containing $\mathrm{Al}$ (AZ, AM alloys) are used commonly in the transportation sector and the other alloys such as ZK, ZC alloys with excellent creep resistant properties are used in critical applications [6-10]. However most of the commercially available alloys exhibit poor thermal stability. However, the addition of ceramic reinforcements such as $\mathrm{Al}_{2} \mathrm{O}_{3}$ and $\mathrm{SiC}$ improves the strength, wear resistance and also, the thermal stability of $\mathrm{Mg}$ and $\mathrm{Mg}$ alloys [11-13]. However, the ductility/formability is often compromised due to the inherent brittleness of the ceramic reinforcements [11-13]. Various researchers have observed the simultaneous improvement in strength and ductility in $\mathrm{Mg}$ and its alloys through the addition of insoluble metallic elements like $\mathrm{Ti}$, Mo and nano-sized ceramic particulates $\left(\mathrm{Al}_{2} \mathrm{O}_{3}, \mathrm{Y}_{2} \mathrm{O}_{3}\right)$. Similar results were also obtained by Eugene et al. through the addition of nano-sized $\mathrm{Cu}$ particulates having limited solubility in $\mathrm{Mg}$ [14-20]. Recently, the high strength, high modulus, hard intermetallic phases (such as $\mathrm{Al}_{3} \mathrm{Ti}$ and $\mathrm{TiB}_{2}$, etc.) were also being used as reinforcements [21-23].

In this work, an attempt is made to synthesize the $\mathrm{Ti}-\mathrm{Cu}$ based intermetallic phases through the mechanical alloying (M.A) process and to use the M.A composite powder as a reinforcement to improve the mechanical response of $\mathrm{Mg}$. The influence of individual $\mathrm{Ti}$ and nano- $\mathrm{Cu}$ elements and their combination (hybrid metallic additions) on the microstructure and mechanical properties of $\mathrm{Mg}$ are studied. The effects of prior ball-milling of hybrid metallic additions on the particle morphology and on the properties of $\mathrm{Mg}$ materials are also discussed. 


\section{Results and Discussion}

\subsection{Synthesis}

Synthesis of pure $\mathrm{Mg}$ and the Mg-based materials required for the study was successfully carried out by the disintegrated melt deposition (DMD) technique followed by hot extrusion. The surface of both the as-cast billets and extruded rods were smooth and free from any visible defects. The absence of any macro-defects in the as-cast and extruded samples indicates the suitability of processing methodology and parameters used in this study $[12,23]$.

\subsection{Density and Porosity}

The density and porosity values of the developed $\mathrm{Mg}$-materials are shown in Table 1 . An increase in the experimental density and porosity values was observed due to the addition of metallic elements. However, the obtained experimental values are relatively low in comparison to similar works and this confirms the successful synthesis of near-dense materials with minimal porosity $(\leq 0.16 \%)$ through DMD technique followed by hot extrusion [12-15].

Table 1. Results of density and porosity measurements.

\begin{tabular}{ccccc}
\hline & & \multicolumn{3}{c}{ Density Measurements } \\
\cline { 3 - 5 } S. No. & Material & $\begin{array}{c}\text { Theoretical Density } \\
\text { (g/cc) }\end{array}$ & $\begin{array}{c}\text { Experimental Density } \\
\text { (g/cc) }\end{array}$ & $\begin{array}{c}\text { Porosity } \\
(\mathbf{\%})\end{array}$ \\
\hline 1 & Pure $\mathrm{Mg}$ & 1.7400 & $1.7397 \pm 0.0015$ & 0.02 \\
2 & $\mathrm{Mg}-\mathrm{Ti}$ & 1.8019 & $1.8002 \pm 0.0017$ & 0.09 \\
3 & $\mathrm{Mg}-\mathrm{Cu}$ & 1.9685 & $1.9681 \pm 0.0010$ & 0.04 \\
4 & $\mathrm{Mg}-\mathrm{Ti}-\mathrm{Cu}$ & 2.1106 & $2.1089 \pm 0.0019$ & 0.16 \\
5 & $\mathrm{Mg}-(\mathrm{Ti}+\mathrm{Cu})_{\mathrm{BM}}$ & 2.1106 & $2.1096 \pm 0.0016$ & 0.09 \\
\hline
\end{tabular}

\section{3. $X$-ray Diffraction}

The x-ray diffractograms of the developed Mg-based materials are shown in Figure 1. In Mg-Ti, only peaks corresponding to pure $\mathrm{Mg}$ and $\mathrm{Ti}$ are observed which indicates the absence of any intermetallic formation between $\mathrm{Mg}$ and $\mathrm{Ti}$ [21-24]. Based on $\mathrm{Mg}-\mathrm{Cu}$ phase diagram, the reaction between $\mathrm{Mg}$ and $\mathrm{Cu}$ would result in $\mathrm{Mg}_{2} \mathrm{Cu}$ intermetallic formation, as observed in the XRD pattern. In $\mathrm{Mg}-(\mathrm{Ti}+\mathrm{Cu})_{\mathrm{BM}}$, in addition to $\mathrm{Mg}, \mathrm{Ti}, \mathrm{Cu}$ and $\mathrm{Mg}_{2} \mathrm{Cu}$ phases, low intensity peaks corresponding to $\mathrm{Ti}-\mathrm{Cu}$ intermetallic phase can be seen; in contrast, in the un-ball milled, directly added $\mathrm{Mg}$-Ti-Cu these peaks are not prominent. Considering that the formation enthalpies of various $\mathrm{Ti}-\mathrm{Cu}$ intermetallics phases such as $\mathrm{TiCu}, \mathrm{TiCu}_{4}, \mathrm{TiCu}_{2}, \mathrm{Ti}_{2} \mathrm{Cu}_{3}, \mathrm{Ti}_{3} \mathrm{Cu}_{4}, \mathrm{Ti}_{2} \mathrm{Cu}, \mathrm{Ti}_{3} \mathrm{Cu}$ and $\mathrm{TiCu}_{3}$ are close to each other, the reaction between $\mathrm{Ti}$ and $\mathrm{Cu}$ can result in any of these intermetallics phases [24-28]. On comparing the experimental diffraction peaks with the standard powder diffraction data, it can be associated to either $\mathrm{Ti}_{2} \mathrm{Cu}_{3}$ or $\mathrm{Ti}_{3} \mathrm{Cu}$ phase. However, as the $\mathrm{Ti}_{2} \mathrm{Cu}_{3}$ intermetallic phase formation occurs only at $\sim 780{ }^{\circ} \mathrm{C}$ to $860{ }^{\circ} \mathrm{C}$ and also at a much slower cooling rate, the observed $\mathrm{Ti}-\mathrm{Cu}$ intermetallics peaks can hence be identified as $\mathrm{Ti}_{3} \mathrm{Cu}[25]$. 
Figure 1. X-ray diffractograms of developed Mg based materials.

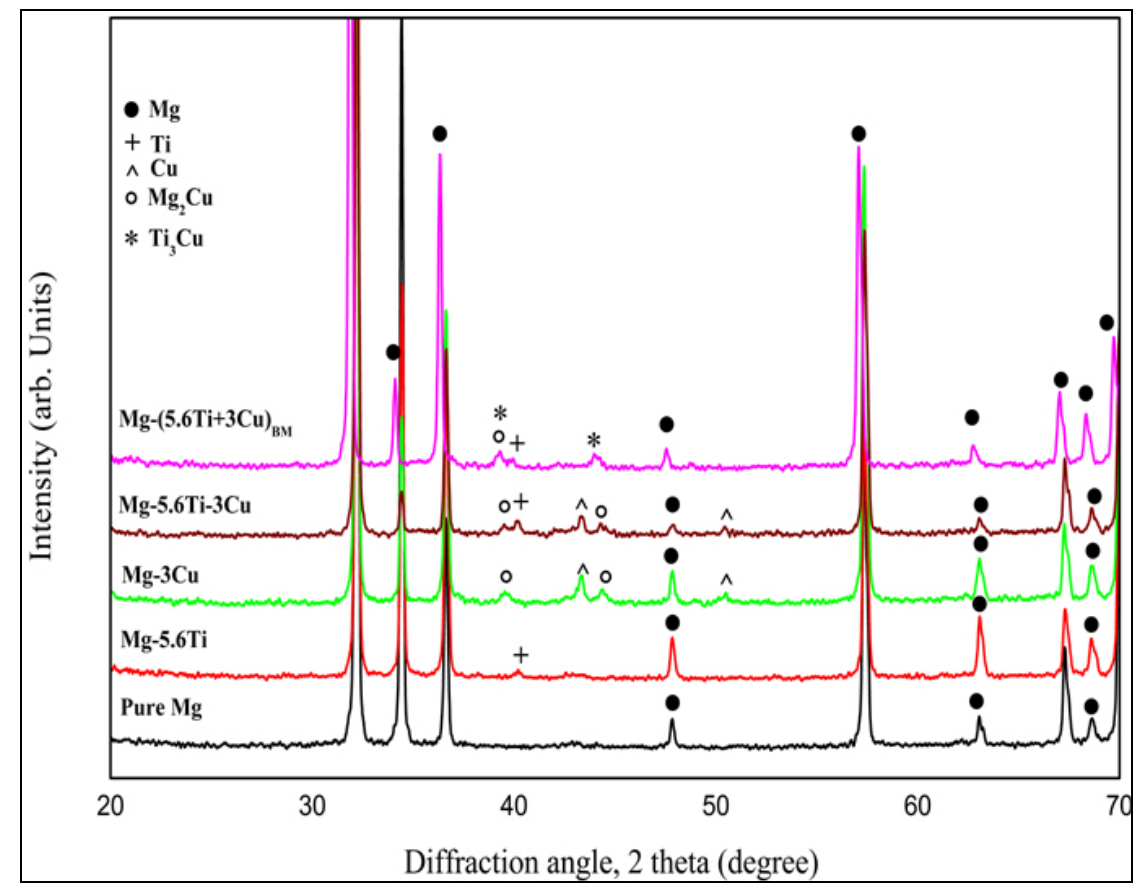

\subsection{Microstructure}

The microstructural observation (Figure $2 \mathrm{a}-\mathrm{d}$ ) reveals the distribution of the metallic particles and the intermetallic/secondary phases formed due to metallic additions. It can be seen from Figure $2 \mathrm{a}$ that the Ti particulates are found to be distributed uniformly in Mg-Ti without any interfacial products. Although no phase formation could occur, effective interfacial bonding with $\mathrm{Mg}$ is facilitated by the good wettability of $\mathrm{Ti}$ by molten $\mathrm{Mg}[22,29]$. Hence the addition of the negligibly soluble $\mathrm{Ti}$ particulates acts as metallic reinforcement in $\mathrm{Mg}$, i.e., $\mathrm{Mg}$-Ti composite, which is composed of $\left(\mathrm{Mg}+\mathrm{Ti}\right.$ ). In $\mathrm{Mg}-\mathrm{Cu}$ (Figure 2b), the reaction between $\mathrm{Mg}$ and $\mathrm{Cu}$ above $725{ }^{\circ} \mathrm{C}$ results in $\mathrm{Mg}+\mathrm{Cu} / \mathrm{Mg}_{2} \mathrm{Cu}$ eutectic mixture as observed from the x-ray diffraction analysis results (Figure 1). Hence the addition of nano- $\mathrm{Cu}$ to $\mathrm{Mg}$ forms $\mathrm{Mg}-\mathrm{Cu}$ alloy with primary $\mathrm{Mg}$ and secondary $\mathrm{Mg}_{2} \mathrm{Cu}$ eutectic phases evenly distributed along the grain boundaries. In both these cases, the presence of either Ti-particles or $\mathrm{Mg}_{2} \mathrm{Cu}$ intermetallics inhibits the grain growth and acts as sites for grain nucleation [19,30], thus resulting in significant grain refinement as observed from the image analysis results in Table 2 and optical micrographs in Figure 3a-c. However, in comparison (Table 2), the grain refinement due to nano- $\mathrm{Cu}$ addition is more prominent than that due to micron-Ti addition. 
Figure 2. SEM micrographs showing the distribution of (a) $\mathrm{Ti}$ particulates in $\mathrm{Mg}$ - $\mathrm{Ti}$ composite; (b) $\mathrm{Cu} / \mathrm{Mg}_{2} \mathrm{Cu}$ intermetallic particulates in $\mathrm{Mg}-\mathrm{Cu}$ alloy; (c) Ti and $\mathrm{Cu} / \mathrm{Mg}_{2} \mathrm{Cu}$ intermetallic particulates in $\mathrm{Mg}$-Ti-Cu composite and (d) $\mathrm{Ti}, \mathrm{Cu} / \mathrm{Mg}_{2} \mathrm{Cu}$ and $\mathrm{Ti}_{3} \mathrm{Cu}$ intermetallic particulates in $\mathrm{Mg}-(\mathrm{Ti}+\mathrm{Cu})_{\mathrm{BM}}$ composite.
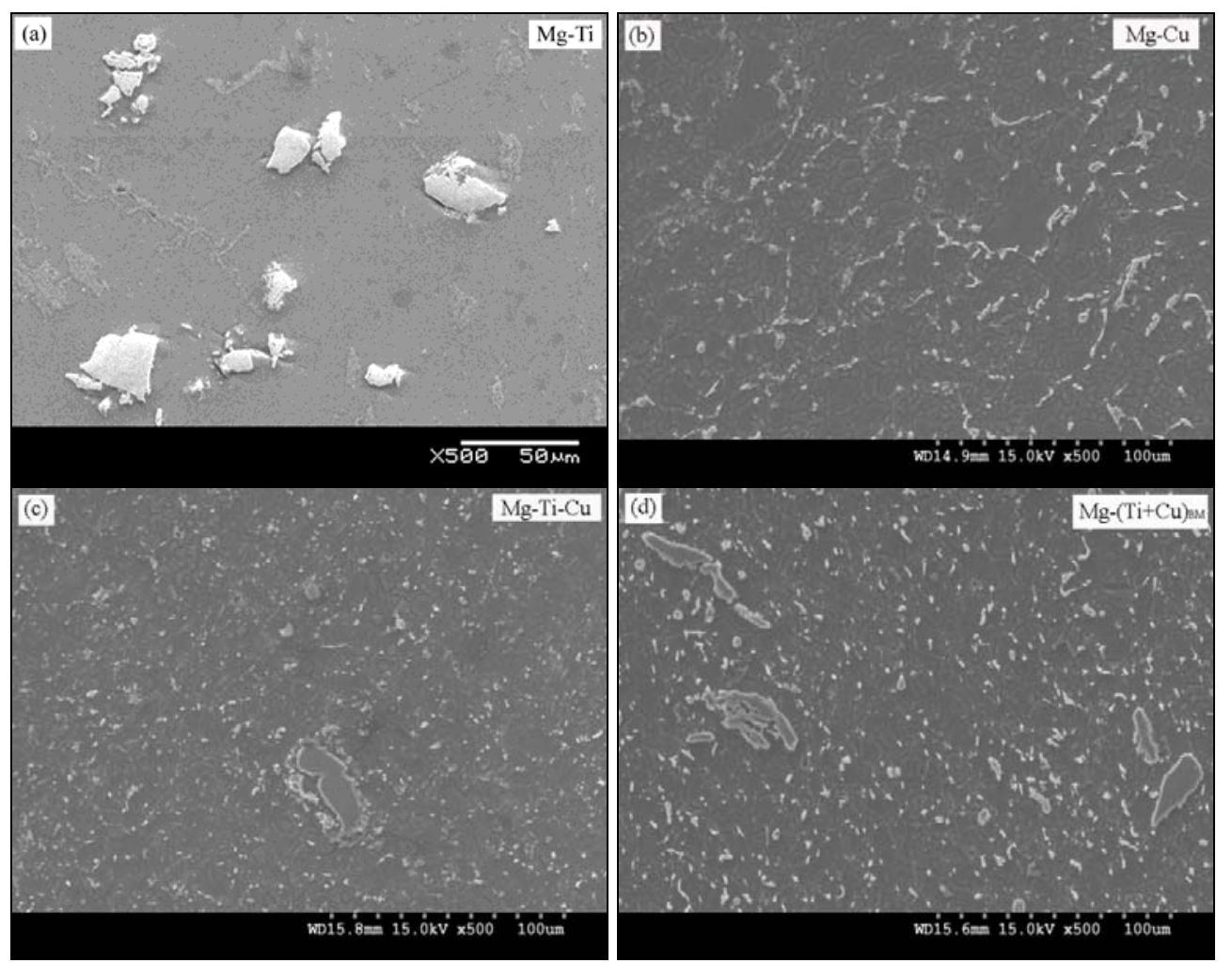

Table 2. Results of microstructure studies ${ }^{\mathrm{a}}$.

\begin{tabular}{cccc}
\hline S. No. & Material & Grain size $(\boldsymbol{\mu m})$ & Aspect ratio $(\boldsymbol{\mu m})$ \\
\hline 1 & Pure $\mathrm{Mg}$ & $21 \pm 3$ & $1.63 \pm 0.44$ \\
2 & $\mathrm{Mg}-\mathrm{Ti}$ & $15 \pm 4$ & $1.58 \pm 0.40$ \\
3 & $\mathrm{Mg}-\mathrm{Cu}$ & $11 \pm 2$ & $1.66 \pm 0.24$ \\
4 & $\mathrm{Mg}-\mathrm{Ti}-\mathrm{Cu}$ & $9 \pm 3$ & $1.60 \pm 0.52$ \\
5 & $\mathrm{Mg}-(\mathrm{Ti}+\mathrm{Cu})_{\mathrm{BM}}$ & $7 \pm 3$ & $1.56 \pm 0.50$ \\
\hline \multicolumn{4}{c}{${ }^{\mathrm{a}}$ Based on approximately 100 grains. }
\end{tabular}

Figure 3. Optical micrographs showing the grain morphology and characteristics of (a) Pure Mg; (b) Mg-Ti; (c) Mg-Cu; (d) Mg-Ti-Cu and (e) $\mathrm{Mg}-(\mathrm{Ti}+\mathrm{Cu})_{\mathrm{BM}}$.
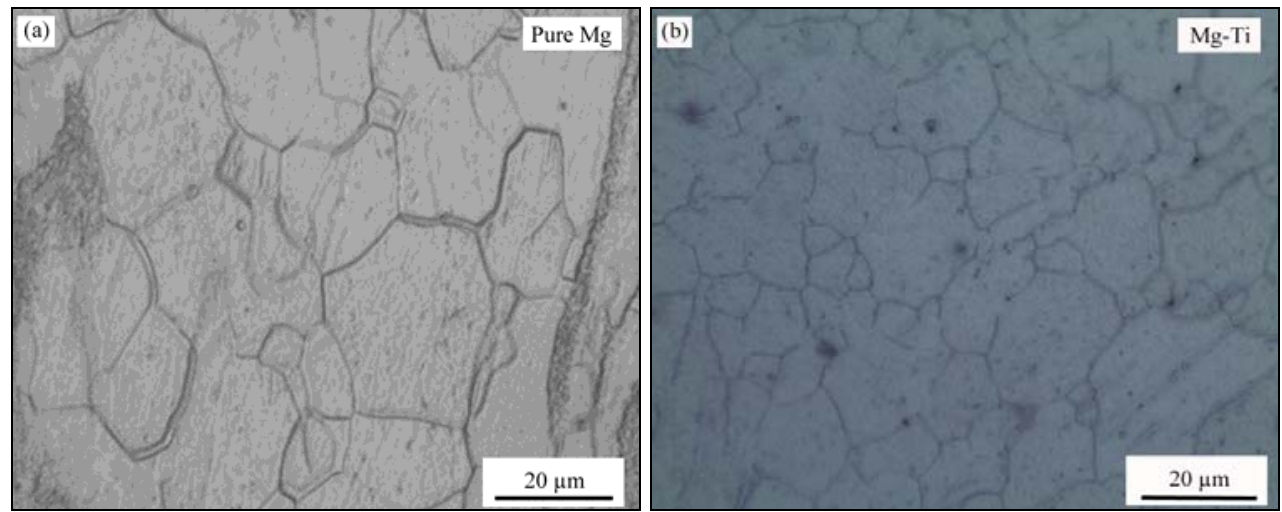
Figure 3. Cont.
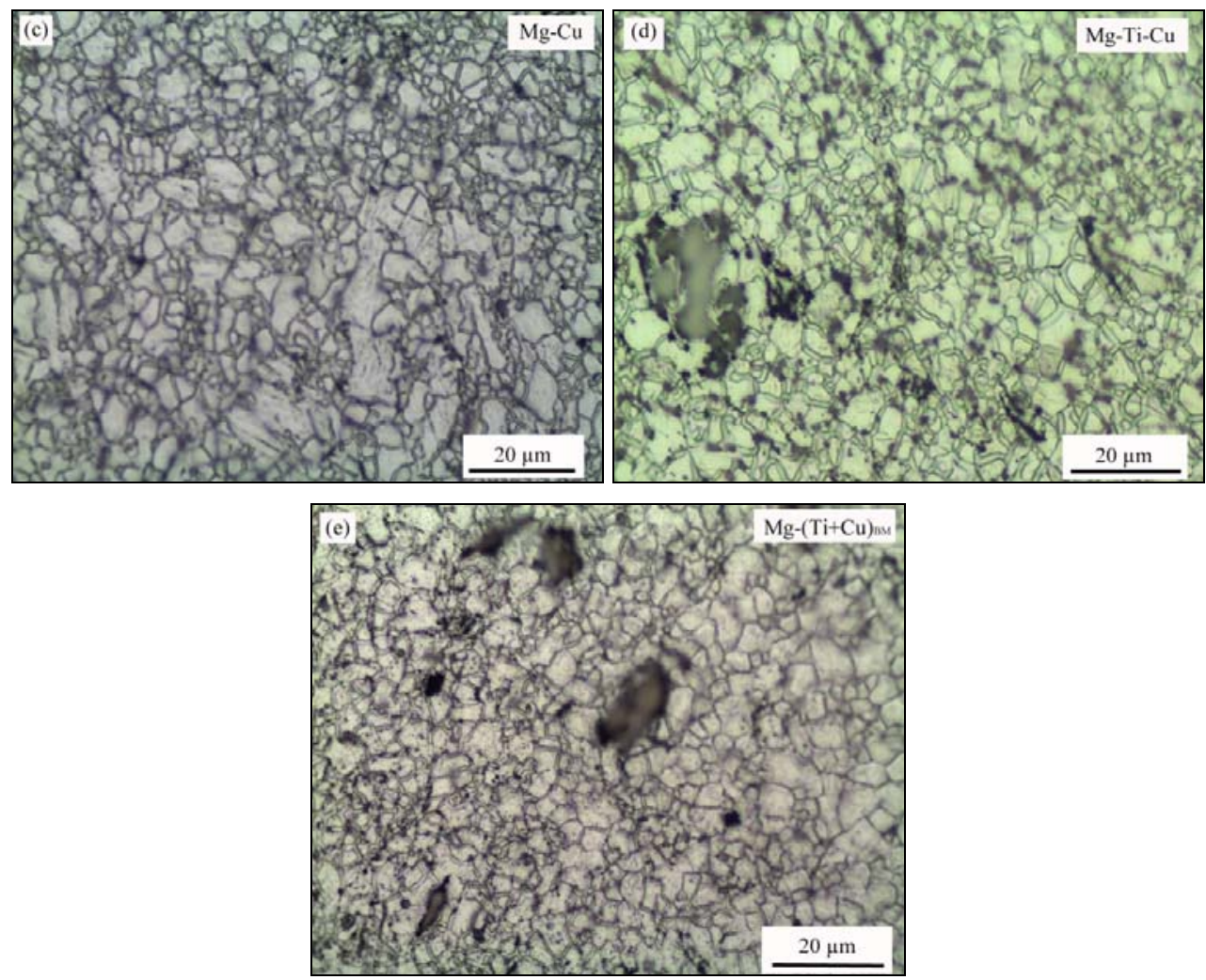

For the Mg-materials developed by the combination of micron-sized $\mathrm{Ti}$ and nano-sized $\mathrm{Cu}$ (i.e., $\mathrm{Mg}-\mathrm{Ti}-\mathrm{Cu}$, Figure $2 \mathrm{c}$ and $\mathrm{Mg}-(\mathrm{Ti}+\mathrm{Cu})_{\mathrm{BM}}$, Figure $2 \mathrm{~d}$ respectively), significant grain refinement due to grain boundary pinning is observed, which is due to the presence of Ti particulates and $\mathrm{Cu} / \mathrm{Mg}_{2} \mathrm{Cu}$ grain boundary precipitates [19,30,31]. As observed from XRD results (Figure 1), no interfacial reaction products form at the $\mathrm{Mg}$ / Ti interface of $\mathrm{Mg}$-Ti-Cu (Figure 2c), whereas in the case of $\mathrm{Mg}-(\mathrm{Ti}+\mathrm{Cu})_{\mathrm{BM}}, \mathrm{Ti}_{3} \mathrm{Cu} / \mathrm{Mg}_{2} \mathrm{Cu}$ intermetallics will form at the $\mathrm{Ti} / \mathrm{Mg}$ interface (Figure $2 \mathrm{~d}$ ). While good wettability between $\mathrm{Mg} / \mathrm{Ti}$ ensures good interfacial bonding [29], the presence of $\mathrm{Ti}_{3} \mathrm{Cu}$ in $\mathrm{Mg}-(\mathrm{Ti}+\mathrm{Cu})_{\mathrm{BM}}$ not only improves the $\mathrm{Ti} / \mathrm{Mg}$-matrix interfacial bonding but is also expected to increase the strength at the interface $[29,32]$. The microstructure of the as-received Ti particulates and the ball milled $(\mathrm{Ti}+\mathrm{Cu})_{\mathrm{BM}}$ particulates indicates that the sharp corners of as-received Ti-particulates (Figure 4a) were rounded off when subjected to ball milling (Figure 4b) [21,22]. The combined metallic additions (micron-Ti and nano- $\mathrm{Cu}$ ) also lead to the reduction in grain size in both the cases, with ball milling or without ball milling, Figure 3d,e. But the grain refinement effect is more pronounced in $\mathrm{Mg}-(\mathrm{Ti}+\mathrm{Cu})_{\mathrm{BM}}$, wherein the metallic elements were added after ball milling. Amongst all the materials developed, $\mathrm{Mg}-(\mathrm{Ti}+\mathrm{Cu})_{\mathrm{BM}}$ shows the least grains size value with an average grain size of $\sim 7 \mu \mathrm{m}$ (Table 2). The grain refinement attributes to the presence of large number of small-sized Ti-particulates obtained due to ball-milling, since the ball milling operation involves repeated flattening, cold-welding and fracture of the particulates which act as sites for grain nucleation to occur $[33,34]$. 
Figure 4. SEM micrographs showing the morphology of (a) as-received Ti particulates and (b) ball milled $(\mathrm{Ti}+\mathrm{Cu})_{\mathrm{BM}}$ powder.
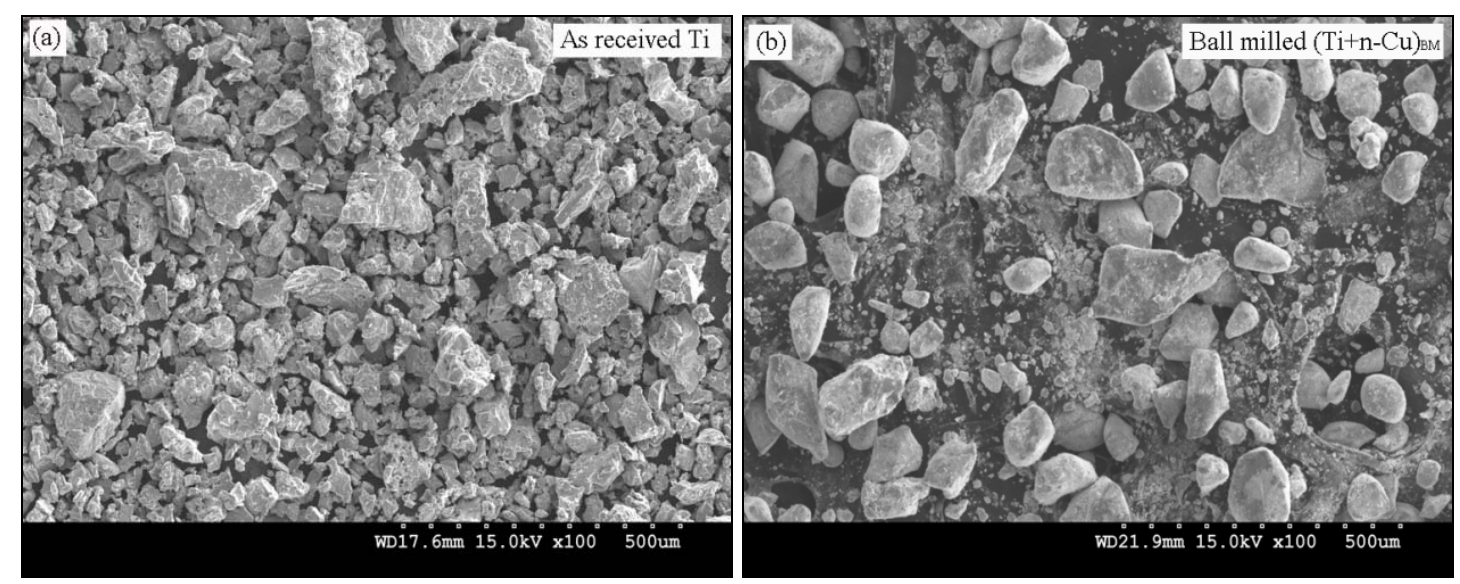

\subsection{Mechanical Properties}

The results of microhardness measurements (Table 3 ) indicate that the addition of metallic elements to pure $\mathrm{Mg}$ results in the increase the hardness values. Relatively higher hardness values are obtained when the metallic elements are added in combination (hybrid metallic elements) compared to those added individually. Among the hybrid addition, $\mathrm{Mg}-(\mathrm{Ti}+\mathrm{Cu})_{\mathrm{BM}}$ incorporated with elements after prior ball milling shows the highest mean microhardness value, i.e., $\sim 90 \%$ increase in comparison to pure $\mathrm{Mg}$.

Table 3. Results of microhardness measurements.

\begin{tabular}{ccc}
\hline S. No. & Material & Microhardness [Hv] \\
\hline 1 & Pure $\mathrm{Mg}$ & $48 \pm 1$ \\
2 & $\mathrm{Mg}-\mathrm{Ti}$ & $71 \pm 2$ \\
3 & $\mathrm{Mg}-\mathrm{Cu}$ & $82 \pm 4$ \\
4 & $\mathrm{Mg}-\mathrm{Ti}-\mathrm{Cu}$ & $86 \pm 2$ \\
5 & $\mathrm{Mg}-(\mathrm{Ti}+\mathrm{Cu})_{\mathrm{BM}}$ & $91 \pm 3$ \\
\hline
\end{tabular}

The mechanical properties evaluation of $\mathrm{Mg}$ incorporated with individual $\mathrm{Ti}$ and nano- $\mathrm{Cu}$ particulates ( $\mathrm{Mg}$ - $\mathrm{Ti}$ composite and $\mathrm{Mg}-\mathrm{Cu}$ alloy) indicates an improvement in strength properties under both tension and compression as observed from Table 4 and Figure 5a, b; yet the increment in strength values in the case of $\mathrm{Mg}-\mathrm{Cu}$ due to nano- $\mathrm{Cu}$ addition is more significant in comparison with micron-sized $\mathrm{Ti}$ addition in Mg-Ti. In both the cases, while the improvement in strength properties under tensile loading occurs with a corresponding increment in tensile ductility, under compressive loading, strength improvement occurred with reduction in compressive ductility. When both the micron- $\mathrm{Ti}$ and nano- $\mathrm{Cu}$ particulates were directly added $(\mathrm{Mg}-\mathrm{Ti}-\mathrm{Cu})$, the tensile strength properties showed an improvement when compared to those with individual elements, but however exhibited low fracture strain values. In contrast, when both the metallic elements were added after ball-milling, $\mathrm{Mg}-(\mathrm{Ti}+\mathrm{Cu})_{\mathrm{BM}}$, the significant improvement in strength values was accompanied by a marginal improvement in failure strain values compared to $\mathrm{Mg}$ (Table 4). Under compressive loads, the combined addition of micron-Ti and nano-Cu particulates either with or without pre-processing by ball 
milling had improved the yield strengths, however the compressive strength and the ductility has been adversely affected. Even though, both the composites with combined metallic addition exhibited lower ductility when compared to individual nano- $\mathrm{Cu}$ addition, the addition of $\mathrm{Ti}$ and nano-Cu particulates after ball milling i.e., $\mathrm{Mg}-(\mathrm{Ti}+\mathrm{Cu})_{\mathrm{BM}}$, revealed higher compressive ductility when compared to the values obtained due to either direct addition $(\mathrm{Mg}-\mathrm{Ti}-\mathrm{Cu})$ or individual Ti addition $(\mathrm{Mg}-\mathrm{Ti})$.

Table 4. Results of room temperature tensile and compression tests.

\begin{tabular}{|c|c|c|c|c|c|c|c|}
\hline \multirow[b]{2}{*}{ S. No. } & \multirow[b]{2}{*}{ Material } & \multicolumn{3}{|c|}{ Tensile properties } & \multicolumn{3}{|c|}{ Compressive properties } \\
\hline & & $\begin{array}{l}0.2 \text { YS } \\
\text { [MPa] }\end{array}$ & $\begin{array}{c}\text { UTS } \\
\text { [MPa] }\end{array}$ & $\begin{array}{c}\text { Failure } \\
\text { Strain } \\
{[\%]}\end{array}$ & $\begin{array}{c}0.2 \\
\text { CYS } \\
\text { [MPa] }\end{array}$ & $\begin{array}{c}\text { UCS } \\
\text { [MPa] }\end{array}$ & $\begin{array}{c}\text { Failure } \\
\text { Strain } \\
{[\%]}\end{array}$ \\
\hline 1 & $\mathrm{Mg}$ & $125 \pm 9$ & $169 \pm 11$ & $6.2 \pm 0.7$ & $74 \pm 3$ & $273 \pm 11$ & $22.7 \pm 4.9$ \\
\hline 2 & $\mathrm{Mg}-\mathrm{Ti}$ & $158 \pm 6$ & $226 \pm 6$ & $8.0 \pm 1.5$ & $85 \pm 3$ & $360 \pm 5$ & $13.6 \pm 1.2$ \\
\hline 3 & $\mathrm{Mg}-\mathrm{Cu}$ & $182 \pm 4$ & $220 \pm 4$ & $8.9 \pm 0.9$ & $102 \pm 8$ & $386 \pm 4$ & $21.1 \pm 1.7$ \\
\hline 4 & $\mathrm{Mg}-\mathrm{Ti}-\mathrm{Cu}$ & $196 \pm 9$ & $227 \pm 4$ & $5.7 \pm 1.6$ & $116 \pm 5$ & $342 \pm 3$ & $16.1 \pm 1.4$ \\
\hline 5 & $\mathrm{Mg}-(\mathrm{Ti}+\mathrm{Cu})_{\mathrm{BM}}$ & $201 \pm 7$ & $265 \pm 11$ & $7.5 \pm 0.8$ & $126 \pm 8$ & $380 \pm 6$ & $19.1 \pm 2.9$ \\
\hline
\end{tabular}

Figure 5. Engineering stress-Strain curves showing the mechanical behavior of developed $\mathrm{Mg}$ materials under (a) tension and (b) compression loading.
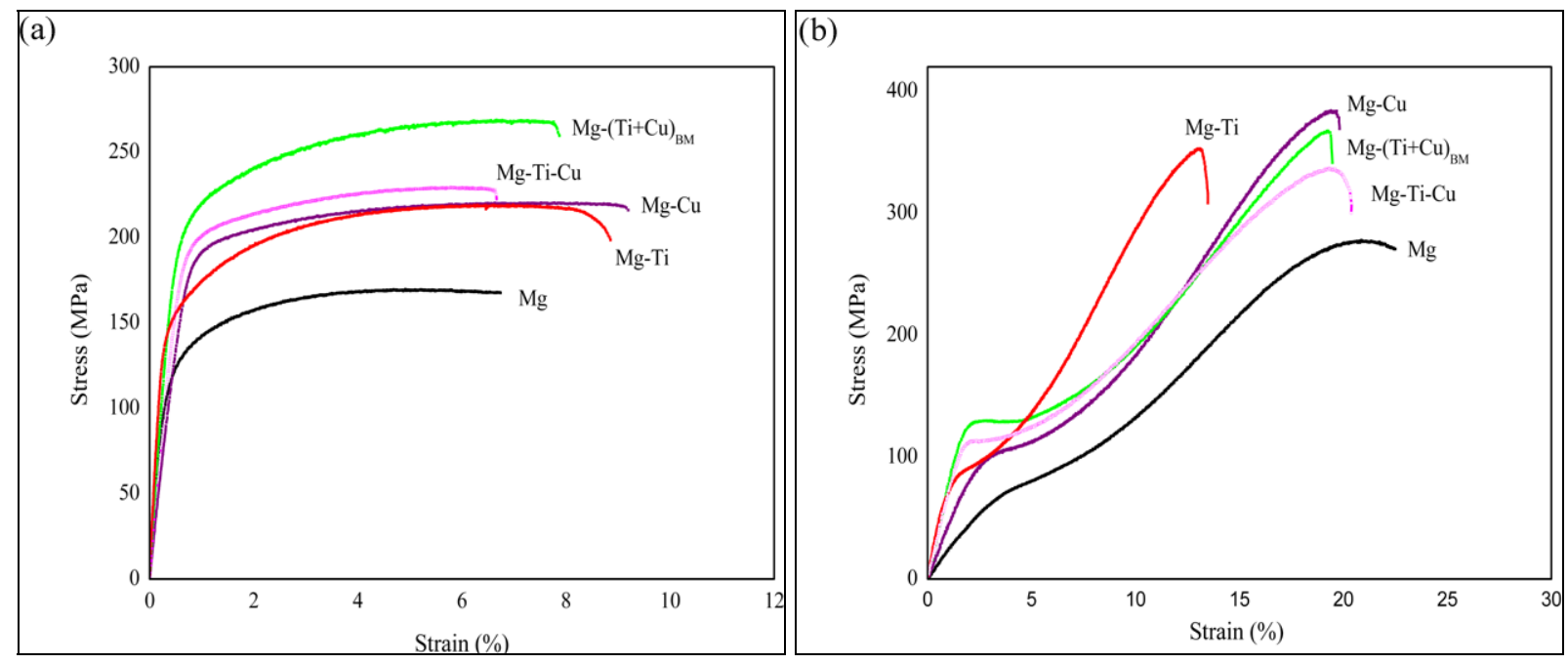

The fracture surfaces of all the test materials under tensile and compressive loading are shown in Figure $6 \mathrm{a}-\mathrm{e}$ and Figure $7 \mathrm{a}-\mathrm{e}$, respectively. The fractographs of the test materials supplement the test results. In case of pure $\mathrm{Mg}$, predominant cleavage mode of fracture is observed under tensile loading as in Figure 6a. While the tensile fracture surface of Mg-Ti indicates Ti-particle interface debonding as seen in Figure 6b, mixed mode fracture with predominant cleavage type fracture Figure $6 \mathrm{c}$ is observed in $\mathrm{Mg}-\mathrm{Cu}$. In case of combined addition, dominant cleavage mode fracture with Ti particle interface debonding (Figure 6d) is observed in the case of $\mathrm{Mg}$-Ti-Cu composites whereas mixed mode fracture with good interface bonding and ductile features of plastic deformation (Figure 6e) is observed in $\mathrm{Mg}$ $(\mathrm{Ti}+\mathrm{Cu})_{\mathrm{BM}}$ composite. The fracture under compressive loading occurred at $\sim 45^{\circ}$ angle with respect to the compression test axis in all the test samples. Under compression, pure Mg exhibited dominant shear failure and showed more shear bands when compared to the developed Mg-based materials. 
These materials on other hand, exhibited rough fracture surfaces with mixed mode of shear and brittle features, as evident from the fractographic evidences shown in Figure 7a-e.

Figure 6. Fractographs of Mg-based materials after tensile loading showing: (a) Dominant cleavage fracture in pure $\mathrm{Mg}$; (b) particle debonding in $\mathrm{Mg}-\mathrm{Ti}$; (c) cleavage fracture with ductile features in $\mathrm{Mg}-\mathrm{Cu}$; (d) dominant particle debonding features in $\mathrm{Mg}-\mathrm{Ti}-\mathrm{Cu}$ and (e) mixed fracture mode with good interface bonding with plastic deformation in $\mathrm{Mg}-(\mathrm{Ti}+\mathrm{Cu})_{\mathrm{BM}}$.

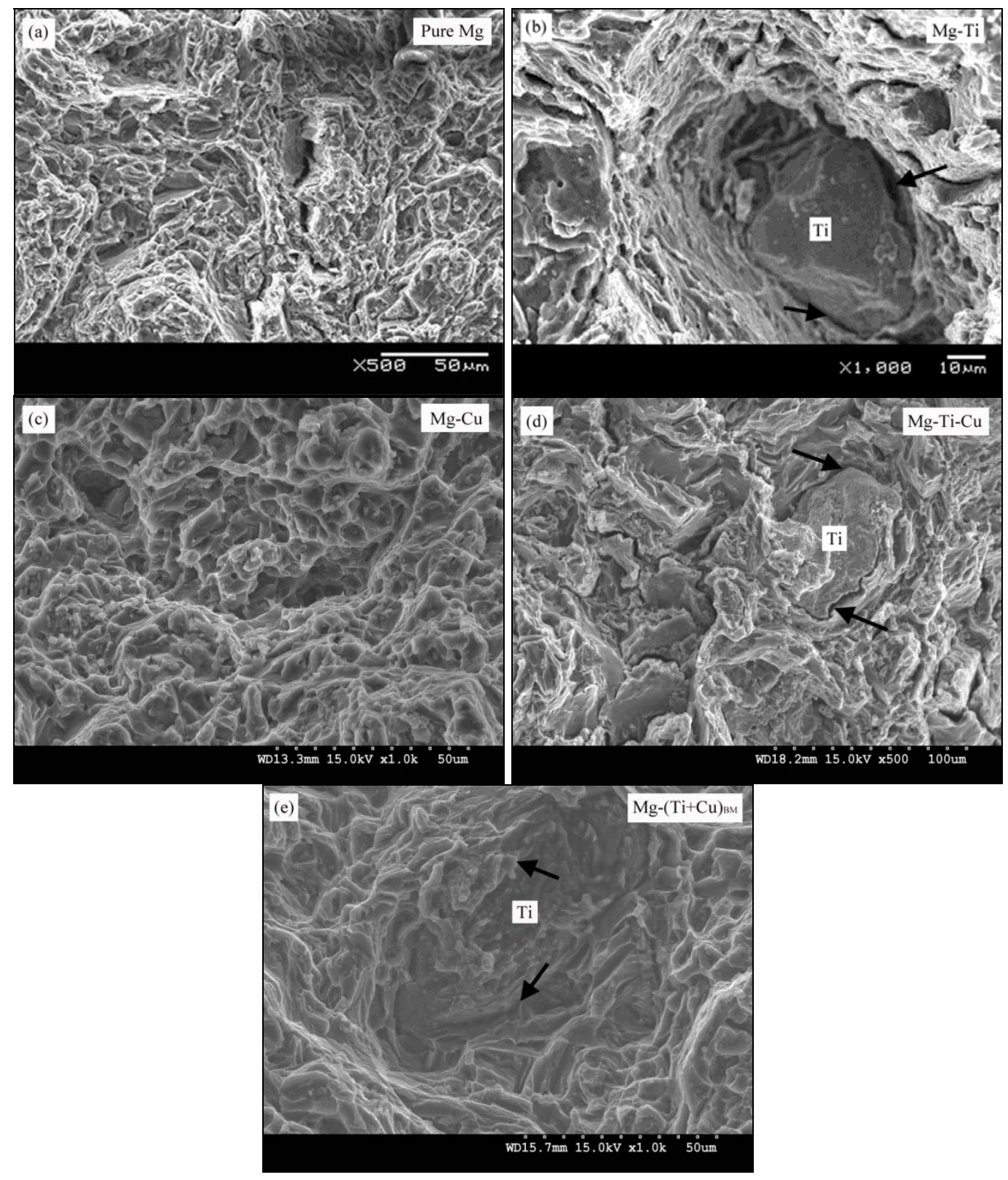

\subsubsection{Influence of Individual Ti Addition}

The mechanical properties improvement in $\mathrm{Mg}$ - Ti composite compared to pure $\mathrm{Mg}$ (Tables 3 and 4) can be ascribed to the microstructural observations, the inherent properties of Ti particulates and the following strengthening effects: (i) thermal residual stress arising from the mismatch between the 
thermal expansion coefficients of $\mathrm{Mg}$ and $\mathrm{Ti}$; (ii) grain refinement; (iii) the increased stress concentration at the pointed corners of Ti-particles [35]; and (iv) increase in the load carrying capacity due to higher hardness of $\mathrm{Ti}$ [31,36,37]. In addition, as reported by various researchers, the difference in CTE values (between the matrix and reinforcements) and the sharp corners of particulate reinforcements contribute to the matrix strengthening through the increased dislocation density at the matrix-reinforcement interface [35-40]. The inherent higher tensile and lower compression fracture strain values of $\mathrm{Ti}$ have resulted in the increased tensile and poor compressive ductility of $\mathrm{Mg}-\mathrm{Ti}$ composite [38,40]. The fracture surface of $\mathrm{Mg}$ - Ti composite under tensile loading indicates mixed mode fracture (ductile + cleavage) (Figure 6b). The hard Ti particulates resist matrix crack propagation, which results in the delay in failure of the composite. Thus the presence of Ti particulates has efficiently improved the load bearing capacity and also the ductility [16]. In the absence of chemical bonding (no phase formation between $\mathrm{Ti}$ and $\mathrm{Mg}$ due to negligible solubility), the good wettability between $\mathrm{Ti}$ and $\mathrm{Mg}$ only governs the mechanical bonding [32]. Hence debonding of Ti particulates occurs once the peak load is reached, rather than Ti-particle fracture. The fracture surface of $\mathrm{Mg}$ - $\mathrm{Ti}$ composite under compressive loads shows relatively rough surface attributing to the dominant shear (shear + brittle) mode fracture (Figure 7a,b).

Figure 7. Fractographs of $\mathrm{Mg}$-based materials under compression showing dominant shear failure. (a) Pure $\mathrm{Mg}$; (b) $\mathrm{Mg}-\mathrm{Ti}$; (c)Mg-Cu; (d) $\mathrm{Mg}-\mathrm{Ti}-\mathrm{Cu}$ and (e) $\mathrm{Mg}-(\mathrm{Ti}+\mathrm{Cu})_{\mathrm{BM}}$.
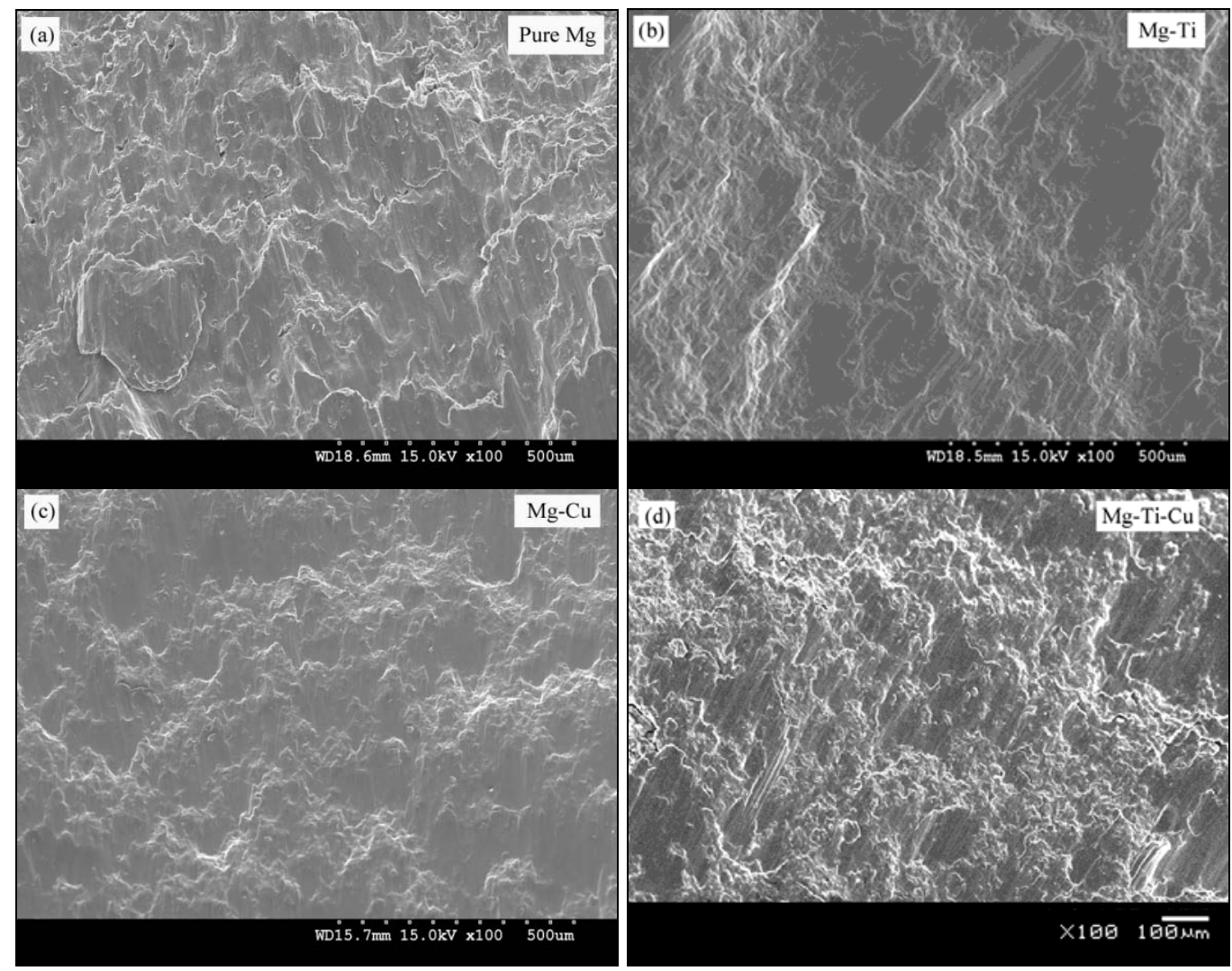
Figure 7. Cont.

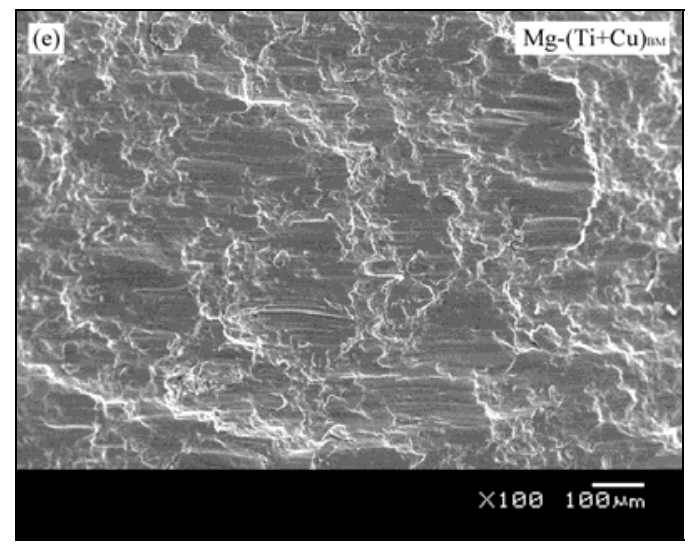

\subsubsection{Influence of Individual Nano-Cu Addition}

The combined effects from: (i) thermal mismatch between the matrix $(\mathrm{Mg})$ and the second phases $\left(\mathrm{Cu} / \mathrm{Mg}_{2} \mathrm{Cu}\right)$; (ii) grain refinement; (iii) matrix work hardening/strain misfit due to the presence of second phase particulates; and (iv) non-basal slip system activation contribute to the mechanical properties enhancement, as reported elsewhere [40-43]. In addition, (v) the presence of harder $\mathrm{Mg}_{2} \mathrm{Cu} / \mathrm{Cu}$ agglomerates and (vi) the efficiency of $\mathrm{Mg}_{2} \mathrm{Cu} / \mathrm{Cu}$ in effective load transfer between $\mathrm{Mg}$ matrix [31], contribute to an appreciable improvement in strength properties. The tensile fracture surface of $\mathrm{Mg}-\mathrm{Cu}$ alloy confirms the mixed mode fracture with dominant cleavage fracture with the evidences of ductile features attributing to the plastic deformation (Figure 6c) when compared to the fracture surface of pure $\mathrm{Mg}$, which shows fracture by cleavage (Figure 6a). The well-bonded second phases $\left(\mathrm{Cu} / \mathrm{Mg}_{2} \mathrm{Cu}\right.$ agglomerates) attribute to efficient load transfer, which results in mixed mode fracture interspersed with cleavage steps and ductile features as shown in Figure 6c. Compressive fracture surfaces of both pure $\mathrm{Mg}$ and $\mathrm{Mg}-\mathrm{Cu}$ alloy shows failure by shear band formation (Figure $7 \mathrm{a}, \mathrm{c}$ ). Thus the combined effects of grain refinement, uniform distribution of nano-sized particulates without agglomeration and slip on extra non-basal slip system attributes to the improvement/little adverse effect in ductility under tension and compression respectively [42].

\subsubsection{Influence of Direct addition of Hybrid (Ti and nano-Cu) Metallic Particulates}

The mechanical properties evaluation indicates a higher value of microhardness and strengths in the case of $\mathrm{Mg}-\mathrm{Ti}-\mathrm{Cu}$ involving the direct addition of hybrid (micro-Ti and nano- $\mathrm{Cu}$ ) metallic addition than that of pure $\mathrm{Mg}$, and individual metallic addition (Tables 3 and 4). However, the strength improvement under tension and compression occurred with the drastic reduction in ductility (Table 4). The strength properties increment follows similar effects observed with the individual addition of metallic elements $(\mathrm{Ti} / \mathrm{nano}-\mathrm{Cu})$, as explained earlier. But the overall increase in second phases and their clustering near the sharp cornered Ti particulates as seen in Figure 4a have resulted in the large reduction in fracture strain as observed from Table 4 [44]. During solidification and subsequent extrusion, these sharp corners of Ti particulates would act as favorable sites for the second phase agglomeration to occur $\left(\mathrm{Cu} / \mathrm{Mg}_{2} \mathrm{Cu}\right.$ formation), due to the high energy and stress concentration associated with irregularly-shaped particulates [32]. Hence, matrix cracking along with Ti-particle 
debonding would occur preferentially at the sites with intermetallic phases and thus results in the poor ductility [21,22,35]. Figure $6 \mathrm{~d}$ shows the image of fracture surface seen in Mg-Ti-Cu indicating the brittle fracture with prominent cracking under tension and dominant shear failure under compression as shown in Figure 7d.

\subsubsection{Influence of Prior Ball-milling of Hybrid (Ti and nano-Cu) Metallic Particulates}

The improvement in the microhardness and strength properties is more significant in $\mathrm{Mg}-(\mathrm{Ti}+\mathrm{Cu})_{\mathrm{BM}}$ as it exhibits the highest values amongst the developed materials. The yield strength under tension and compression has improved by $\sim 60 \%$ and $\sim 70 \%$ respectively when compared to pure $\mathrm{Mg}$. While the strength improvement under tensile loading is accompanied by corresponding increment in tensile ductility by $\sim 20 \%$, a slight reduction in ductility $(\sim 16 \%)$ is seen under compression due to combined metallic addition (Table 4). The increment in strength properties in $\mathrm{Mg}-(\mathrm{Ti}+\mathrm{Cu})_{\mathrm{BM}}$ composite is due to the presence of relatively hard metallic particulates (Ti) and intermetallic phases $\left(\mathrm{Mg}_{2} \mathrm{Cu}, \mathrm{Ti}_{3} \mathrm{Cu}\right)$, which in turn gives rise to one or more of the strengthening effects arising from individual $\mathrm{Ti}$ or nano- $\mathrm{Cu}$ and effective load transfer due to good interfacial bonding [21,22,36,37,41]. Unlike $\mathrm{Mg}-\mathrm{Ti}-\mathrm{Cu}$, wherein the sharp and angular particles contribute to stress concentration and resulting in lower ductility (Table 4), the improved ductility under tension in $\mathrm{Mg}-(\mathrm{Ti}+\mathrm{Cu})_{\mathrm{BM}}$ is due to the change in morphology and size of the micron-sized Ti-particles. Hence, the substitution of particles with blunted and rounded edges aid in the retention in tensile ductility without affecting the strengthening effect. These results are similar to those observed by various researchers [22,35]. Further, the presence of blunt-edged particles would also minimize the preferential agglomeration of nano- $\mathrm{Cu}$ in Ti-particle corners, as observed in directly added $\mathrm{Mg}$-Ti-Cu. Also, as the presence of $\mathrm{Ti}_{3} \mathrm{Cu}$ intermetallic improves the interfacial bonding at the $\mathrm{Mg} /$ particle interface, it would also improve the shear strength at the interface, thereby increasing the load bearing capacity [44] However, the relatively lower ductility under compression of $\mathrm{Mg}-(\mathrm{Ti}+\mathrm{Cu})_{\mathrm{BM}}$ when compared to pure $\mathrm{Mg}$ (although higher than $\mathrm{Mg}-\mathrm{Ti}-\mathrm{Cu}$ ) is attributed to the presence of inherent properties of harder Ti-particles and $\mathrm{Mg}_{2} \mathrm{Cu} / \mathrm{Cu}, \mathrm{Ti}_{3} \mathrm{Cu}$ intermetallics. The tensile fracture surface of $\mathrm{Mg}-(\mathrm{Ti}+\mathrm{Cu})_{\mathrm{BM}}$ is thus characterized by mixed mode fracture with significant plastic deformation respectively as shown in Figure 6e, while the compression fractographs indicates shear mode fracture with rough surfaces as observed in Figure 7e.

To summarize, the incorporation of metallic elements to pure $\mathrm{Mg}$ improved the mechanical properties significantly. While the addition of insoluble micron-sized element (Ti) acted as a metallic reinforcement and formed the $\mathrm{Mg}$-Ti composite, the addition of metallic element with limited solubility $(\mathrm{Cu})$ formed the $\mathrm{Mg}-\mathrm{Cu}$ alloy. Both these additions resulted in the enhancement of strength and ductility. When a combination of soluble and insoluble elements was incorporated in $\mathrm{Mg}$, the resulting microstructure and mechanical properties depended on their mode of addition. The direct addition of elements to pure $\mathrm{Mg}$ resulted in properties that were similar to or lower than that of $\mathrm{Mg}-\mathrm{Ti}$ and $\mathrm{Mg}-\mathrm{Cu}$. On the other hand, the prior ball milling of the soluble and insoluble elements not only changed their morphology but also resulted in solid-state reaction forming in-situ $\mathrm{Ti}_{3} \mathrm{Cu}$ intermetallic phase, thus markedly improving the strength properties of the composite. Hence, depending on the 
final application, the metallic alloying/reinforcing elements and their combination should be judiciously selected.

\section{Experimental Procedure}

\subsection{Materials}

Mg turnings of $>99.9 \%$ purity (ACROS Organics, New Jersey, NJ, USA), was used as the matrix material. The metallic additions were: (i) insoluble micron sized Ti particulates, $\mathrm{Mg}$-Ti; (ii) addition of nano sized $\mathrm{Cu}$ particulates with limited solubility, $\mathrm{Mg}-\mathrm{Cu}$; (iii) addition of a combination of $\mathrm{Ti}$ and nano- $\mathrm{Cu}$ particulates by (a) incorporation after pre-processing, $\mathrm{Mg}-(\mathrm{Ti}+\mathrm{Cu})_{\mathrm{BM}}$ and (b) direct addition without any pre-processing, $\mathrm{Mg}-\mathrm{Ti}-\mathrm{Cu}$. Elemental Ti particulates of particle size $<140 \mu \mathrm{m}$ (purity 98\%) supplied by Merck, and nano-Cu particulates of average particle size $\sim 50 \mathrm{~nm}$ (purity 99\%) supplied by Nanostructure and Amorphous were used. The compositions of the $\mathrm{Ti}$ and nano- $\mathrm{Cu}$ were identified as $5.6 \mathrm{wt} \%$ and $3 \mathrm{wt} \%$ respectively based on previous investigations [20,21].

\subsection{Processing}

\subsubsection{Pre-processing of Metallic Additions}

The pre-processing of the metallic additions was carried out using ball-milling, which is a solid-state processing technique. Retsch PM-400 mechanical alloying machine was used for ball-milling the metallic elements ( $\mathrm{Ti}$ and nano- $\mathrm{Cu})$, herein referred to as $(\mathrm{Ti}+\mathrm{Cu})_{\mathrm{BM}}$. Prior to ball milling, the elemental $\mathrm{Ti}$ and nano- $\mathrm{Cu}$ particulates were blended for 1 hour (with $0.3 \mathrm{wt} \%$ stearic acid as process control agent) so as to ensure uniform mixing of $\mathrm{Ti}$ and nano- $\mathrm{Cu}$ particulates. After blending, hardened stainless steel balls of diameter $15 \mathrm{~mm}$ were added and the blended mixture was ball-milled for 2 hours. Ball-milling was carried out so as to allow the metallic particles to react with each other and to get the nano-sized $\mathrm{Cu}$ particles effectively embedded in the micron size Ti-particles [22,23]. The ball to powder weight ratio was kept at 20:1 and the speed of the milling machine was set at $200 \mathrm{rpm}$ during the blending and ball milling processes [21-23].

\subsubsection{Melting and Casting}

The Mg-based materials were prepared using the DMD technique [12,13]. The Mg turnings together with the metallic additions were heated in a graphite crucible to $750{ }^{\circ} \mathrm{C}$ in an electrical resistance furnace, under inert argon gas protective atmosphere. The superheated molten slurry was stirred for $5 \mathrm{~min}$ at $460 \mathrm{rpm}$ using a twin blade (pitch $45^{\circ}$ ) mild steel impeller. This facilitates uniform distribution of the incorporated metallic elements in the Mg-matrix. The impeller was coated with Zirtex $25\left(86 \% \mathrm{ZrO}_{2}, 8.8 \% \mathrm{Y}_{2} \mathrm{O}_{3}, 3.6 \% \mathrm{SiO}_{2}, 1.2 \% \mathrm{~K}_{2} \mathrm{O}\right.$ and $\mathrm{Na}_{2} \mathrm{O}$, and $0.3 \%$ trace inorganic) to avoid iron contamination of the molten metal. The melt was then released through a $10 \mathrm{~mm}$ diameter orifice at the base of the crucible and it was disintegrated by two jets of argon gas (at a flow rate of $\sim 25 \mathrm{~L} / \mathrm{min}$ ), which was located at a distance $265 \mathrm{~mm}$ from the melt pouring point and oriented normal to the melt stream. The disintegrated melt slurry was subsequently deposited onto a metallic substrate located $500 \mathrm{~mm}$ from the disintegration point. An ingot of $40 \mathrm{~mm}$ diameter was obtained following the 
deposition stage. The synthesis of pure Mg was carried out in a similar fashion, except that no alloying elements were added.

\subsubsection{Hot Extrusion}

The pure $\mathrm{Mg}$ and the Mg-based materials obtained were machined to a diameter of $36 \mathrm{~mm}$ and soaked at $400{ }^{\circ} \mathrm{C}$ for $60 \mathrm{~min}$. Hot extrusion was then carried out using a $150 \mathrm{~T}$ hydraulic press at $350{ }^{\circ} \mathrm{C}$ with an extrusion ratio of $20.25: 1$ to obtain rods of $8 \mathrm{~mm}$ in diameter. Samples from the extruded rods were used for further characterization as detailed in the next section.

\subsection{Materials Characterization}

\subsubsection{Density Measurements}

The experimental mass densities of pure $\mathrm{Mg}$ and the $\mathrm{Mg}$-based materials developed were determined using Archimedes' principle. This involved weighing the sample in air and then in distilled water using an A\&D ER-182A electronic balance with an accuracy of $\pm 0.0001 \mathrm{~g}$. The theoretical densities of composites were calculated using the rule of mixtures [10].

\subsubsection{X-ray Diffraction Studies}

X-ray diffraction (XRD) analysis was carried out on the polished samples of developed Mg-materials using an automated Shimadzu LAB X XRD-6000 diffractometer. The samples were exposed to $\mathrm{Cu} \mathrm{K} \alpha$ radiation $\left(\lambda=1.54056 \mathrm{~A}^{\circ}\right)$ at a scanning speed of $2 \% \mathrm{~min}$. The Bragg angles and the values of interplanar spacing, $\mathrm{d}$, obtained were matched with standard values for $\mathrm{Mg}, \mathrm{Ti}, \mathrm{Cu}$ and other related phases.

\subsubsection{Microstructural Characterization}

The grain morphology and distribution of second phases/particulates in $\mathrm{Mg}$ matrix were studied on the as-polished samples. A Hitachi S-4300 field emission scanning electron microscope (FESEM) equipped with energy dispersive X-ray spectroscopy (EDS), a Jeol JSM-5800 LV scanning electron microscope (SEM), an Olympus metallographic optical microscope and Scion image analysis software were used for this purpose. The microstructure of the as-received $\mathrm{Ti}$ and ball milled $(\mathrm{Ti}+\mathrm{Cu})_{\mathrm{BM}}$ powders were also investigated using SEM for determining the average particle size and particle morphology.

\subsubsection{Mechanical Properties Measurements}

The microhardness measurements were carried out on the as-polished samples of pure $\mathrm{Mg}$ and other Mg-based materials using Matsuzawa MXT 50 automatic digital Microhardness tester. Vickers indenter under a test load of $25 \mathrm{gf}$ and a dwell time of $15 \mathrm{~s}$ was used to perform the micro hardness tests in accordance with the ASTM standard E3 84-99. The tests were conducted on three samples for each composition for $10-15$ repeatable readings. 
A fully automated servo-hydraulic mechanical testing machine, Model-MTS 810 was used to determine the tensile properties of the Mg-based materials, in accordance with ASTM test method E8M-96. The crosshead speed was set at $0.254 \mathrm{~mm} / \mathrm{min}$. Specimens with $5 \mathrm{~mm}$ diameter and $25 \mathrm{~mm}$ gauge length was used. Instron 2630-100 series clip-on type extensometer was used to measure the failure strain. For each composition, a minimum of 5 tests were conducted to obtain repeatable values. The compressive properties of the developed Mg-based materials along with pure $\mathrm{Mg}$ were determined in accordance with ASTM test method E9-89a using MTS 810 testing machine with a crosshead speed set at $0.04 \mathrm{~mm} / \mathrm{min}$. Compressive test specimens of $8 \mathrm{~mm}$ diameter with length to diameter ratio, 1/d 1, were used. For each composition, a minimum of 5 tests were conducted to obtain repeatable values. The fracture surface analyses of all the Mg-materials, tested under tension and compression, were studied using Jeol JSM-5800 LV SEM and Hitachi S-4300 FESEM.

\section{Conclusions}

The following are the conclusions that could be drawn from the present study:

(1) The addition of micron sized (Ti) particulates with negligible solubility and nano-sized $\mathrm{Cu}$ particulates with limited solubility in $\mathrm{Mg}$, resulted in the formation of $\mathrm{Mg}$-Ti composite and $\mathrm{Mg}-\mathrm{Cu}$ alloy, respectively.

(2) While the inherent properties of Ti such as hardness, ductility and the good wettability of Ti and $\mathrm{Mg}$ enhanced the strength and ductility of the $\mathrm{Mg}$ - $\mathrm{Ti}$ composite, the $\mathrm{Mg}_{2} \mathrm{Cu}$ eutectic phase formation refined the grain size and significantly improved the mechanical properties in $\mathrm{Mg}-\mathrm{Cu}$ alloy.

(3) The effects of the combined addition of (micro-Ti and nano- $\mathrm{Cu}$ ) metallic elements on the properties of $\mathrm{Mg}$ primarily depend on their method of addition.

(4) In $\mathrm{Mg}-\mathrm{Ti}-\mathrm{Cu}$, involving direct addition of micro-Ti and nano- $\mathrm{Cu}$, strength properties improvement with an adverse effect on ductility occurred and the reduction in ductility is attributed to the overall higher volume fraction of the metallic particulates and intermetallics, morphology of micron-sized Ti-particle, formation and agglomeration of $\mathrm{Mg}_{2} \mathrm{Cu} / \mathrm{Cu}$.

(5) The best strength properties were obtained in $\mathrm{Mg}-(\mathrm{Ti}+\mathrm{Cu})_{\mathrm{BM}}$, through the combined addition of micron-sized $\mathrm{Ti}$ particles and nano-sized $\mathrm{Cu}$ particles after prior ball-milling. The elimination of sharp corners of $\mathrm{Ti}$ particulates and $\mathrm{Ti}_{3} \mathrm{Cu}$ intermetallic formation during ball milling attributes to the simultaneous improvement in strength and ductility when compared to $\mathrm{Mg}-5.6 \mathrm{Ti}-3 \mathrm{Cu}$.

\section{Acknowledgements}

The authors gratefully acknowledge the financial support from Qatar National Research Foundation through research grant \# NPRP08-424-2-171 (R-265-000-346-597). One of the authors, Sankaranarayanan, sincerely thanks the NUS research scholarship for its support for his graduate study.

\section{Conflict of Interest}

The authors declare no conflict of interest. 


\section{References}

1. Kainer, K.U. Metal Matrix Composites: Custom-Made Materials for Automotive and Aerospace Engineering; Wiley-VCH: Weinheim, Germany, 2006.

2. Emley, E.F. Principles of Magnesium Technology; Pergamon Press: Oxford, UK, 1966.

3. Smithells, C.J. Metals Reference Book, 5th ed.; Butterworth's \& Co. Ltd.: London, UK, 1976.

4. Mordike, B.L.; Ebert, T. Magnesium: Properties-applications-potential. Mater. Sci. Eng. A 2001, $302(1), 37-45$.

5. Tharumarajah, A.; Koltun, P. Is there an environmental advantage of using magnesium components for light-weighting cars? J. Cleaner Prod. 2007, 15, 1007-1013.

6. Polmear, I.J. Magnesium alloys and Applications. Mater. Sci. Technol. 1994, 10, 1-16.

7. Pettersen, G.; Westengen, H.; Høier, R.; Lohne, O. Microstructure of a pressure die cast magnesium - 4 wt \% aluminium alloy modified with rare earth additions. Mater. Sci. Eng. A 1996, 207, 115-120.

8. Du, W.; Sun, Y.; Min, X.; Xue, F.; Zhu, M.; Wu, D. Microstructure and mechanical properties of Mg-Al based alloy with calcium and rare earth additions. Mater. Sci. Eng. A 2003, 356, 1-7.

9. Luo, A.; Perquleryuz, M.O. Cast magnesium alloys for elevated temperature applications. J. Mater. Sci. 1994, 29, 5259-5271.

10. Tang, W.N.; Park, S.S.; You, B.S. Effect of the Zn content on the microstructure and mechanical properties of indirect-extruded Mg-5Sn-xZn alloys. Mater. Des. 2011, 32, 3537-3543.

11. Fritze, C.; Berek, H.; Kainer, K.U.; Mielke, S.; Wielage, B. Magnesium Alloys and Their Applications; Mordike, B.L., Kainer, K.U., Eds.; Werkstoff-Information-sgesellschaft: Frankfurt, Germany, 1998; pp. 635-640.

12. Gupta, M.; Lai, M.O.; Sarvanaranganathan, D. Synthesis, microstructure and properties characterization of disintegrated melt deposited $\mathrm{Mg} / \mathrm{SiC}$ composites. J. Mater. Sci. 2000, 35, 2155-2165.

13. Ugandhar, S.; Gupta, M.; Sinha, S.K. Enhancing strength and ductility of $\mathrm{Mg} / \mathrm{SiC}$ composites using recrystallization heat treatment. Compos. Struct. 2006, 72, 266-272.

14. Hassan, S.F.; Gupta, M. Development of a novel magnesium/nickel composite with improved mechanical properties. J. Alloys Compd. 2002, 335, L10-L15.

15. Hassan, S.F.; Gupta, M. Development of a novel magnesium-copper based composite with improved mechanical properties. Mater. Res. Bull. 2002, 37, 377-389.

16. Pérez, P.; Garcés, G.; Adeva, P. Mechanical properties of a Mg-10 (vol \%) Ti composite. Compos. Sci. Technol. 2004, 64, 145-151.

17. Ferkel, H.; Mordike, B.L. Magnesium strengthened by SiC nanoparticles. Mater. Sci. Eng. A. 2001, 298, 193-199.

18. Dieringa, H. Properties of magnesium alloys reinforced with nanoparticles and carbon nanotubes: A review. J. Mater. Sci. 2011, 46, 289-306.

19. Goh, C.S.; Wei, J.; Lee, L.C.; Gupta, M. Simultaneous enhancement in strength and ductility by reinforcing magnesium with carbon nanotubes. Mater. Sci. Eng. A. 2006, 423, 153-156.

20. Hassan, S.F.; Gupta, M. Effect of particulate size of $\mathrm{Al}_{2} \mathrm{O}_{3}$ reinforcement on microstructure and mechanical behavior of solidification processed elemental Mg. J. Alloys Compd. 2006, 419, 84-90. 
21. Sankaranarayanan, S.; Jayalakshmi, S.; Gupta, M. Effect of individual and combined addition of micro/nano-sized metallic elements on the microstructure and mechanical properties of pure $\mathrm{Mg}$. Mater. Des. 2012, 37, 274-284.

22. Sankaranarayanan, S.; Jayalakshmi, S.; Gupta, M. Effect of addition of mutually soluble and insoluble metallic elements on the microstructure, tensile and compressive properties of pure magnesium. Mater. Sci. Eng A. 2011, 530, 149-160.

23. Zhang, X.; Wang, H.; Liao, L.; Teng, X.; Ma, N. The mechanical properties of magnesium matrix composites reinforced with $\left(\mathrm{TiB}_{2}+\mathrm{TiC}\right)$ ceramic particulates. Mater. Lett. 2005, 59, 2105-2109.

24. Binary Alloy Phase Diagram [Electronic Resource], 2nd ed.; ASM International: Materials Park, OH, USA, 1996.

25. Andrieux, J.; Dezellus, O.; Bosselet, F.; Sacerdote-Peronnet, M.; Sigala, C.; Chiriac, R. Details on the formation of $\mathrm{Ti}_{2} \mathrm{Cu}_{3}$ in the $\mathrm{Ag}-\mathrm{Cu}-\mathrm{Ti}$ system in the temperature range 790 to $860 \mathrm{C}$. J. Phase Equilib. Diffus. 2008, 29 (2), 156-162.

26. Konieczny, M. Processing and microstructural characterisation of laminated Ti-intermetallic composites synthesised using Ti and Cu foils. Mater. Lett. 2008, 62, 2600-2602.

27. Lütjering, G.; Weissmann, S. Mechanical properties and structure of age-hardened Ti-Cu alloys. Metall. Mater. Trans. B 1970, 1(6), 1641-1649.

28. Anisimova, M.V.; Nuzhdin, G.A. New functional compositions of mixture for superhard composites based on bn blende. Refract. Ind. Ceram. 1999, 40 (3-4), 98-100.

29. Kondoh, K.; Kawakami, M.; Imai, H.; Umeda, J.; Fujii, H. Wettability of pure Ti by molten pure Mg droplets. Acta Mater. 2010, 58, 606-614.

30. Gupta, M.; Srivatsan, T.S. Microstructure and grain growth behavior of an aluminum alloy metal matrix composite processed by disintegrated melt deposition. J. Mater. Eng. Perform. 1999, 8 (4), $473-478$.

31. Lloyd, D.J. Particle reinforced aluminium and magnesium matrix composites. Int Mater. Rev. 1994, 39 (1), 1-23.

32. Ahmed, S.; Jones, F.R. Effect of particulate agglomeration and the residual stress state on the modulus of filled resin. Part II: Moduli of untreated sand and glass bead filled composites. Composites 1990, 21, 81-84.

33. Suryanarayana, C. Mechanical Alloying and Milling; CRC Press: NewYork, NY, USA, 2004.

34. Habibi, M.K.; Pouriayevali, H.; Gupta, M. Effect of strain rate and ball milling of reinforcement on the compressive response of magnesium composites. Composites Part A 2011, 42 (12), 1920-1929.

35. Qin, S.; Chen, C.; Zhang, G.; Wang, W.; Wang, Z. The effect of particle shape on ductility of SiCp reinforced 6061 Al matrix composites. Mater. Sci. Eng. A 1999, 272, 363-370.

36. Dieter, G. Mechanical Metallurgy; McGraw-Hill: New York, NY, USA, 1986.

37. Ibrahim, I.A.; Mohamed, F.A.; Lavernia, E.J. Particulate reinforced metal matrix composites-A review. J. Mater. Sci. 1991, 26, 1137-1156.

38. Arsenault, R.J.; Shi, N. Dislocation generation due to differences between coefficients of thermal expansion. Mater. Sci. Eng. 1986, 81, 175-187.

39. Mordike, B.L.; Lukac, P. Interfaces in magnesium-based composites. Surf. Interface Anal. 2001, 31, 682-685. 
40. Barrett, P.F. Compressive Properties of Titanium Sheet at Elevated Temperatures; National Advisory Committee for Aeronautics: Washington, DC, USA, 1950; Technical Note 2038.

41. Meijer, G.; Ellyin, F.; Xia, Z. Aspects of residual thermal stress/strain in particle reinforced metal matrix composites. Composites B 2000, 31, 29-37.

42. Agnew, S.R.; Duygulu, O. Plastic anisotropy and the role of non-basal slip in magnesium alloy AZ31B. Int. J. Plast. 2005, 21, 1161-1193.

43. Gupta, M.; Nai, S. Magnesium, Magnesium Alloys and Magnesium Composites; John Wiley: Hoboken, NJ, USA, 2011.

44. Ksiazek, M.; Sobczak, N.; Mikulowski, B.; Radziwill, W.; Surowiak, I. Wetting and bonding strength in $\mathrm{Al} / \mathrm{Al}_{2} \mathrm{O}_{3}$ system. Mater. Sci. Eng. A 2002, 324 (1-2), 162-167.

(C) 2012 by the authors; licensee MDPI, Basel, Switzerland. This article is an open access article distributed under the terms and conditions of the Creative Commons Attribution license (http://creativecommons.org/licenses/by/3.0/). 